\title{
The NF-кB Family of Transcription Factors and Its Regulation
}

\author{
Andrea Oeckinghaus ${ }^{1,2}$ and Sankar Ghosh ${ }^{1,2}$ \\ ${ }^{1}$ Department of Immunobiology and Department of Molecular Biophysics and Biochemistry, Yale University \\ School of Medicine, New Haven, Connecticut 06520 \\ ${ }^{2}$ Department of Microbiology and Immunology, Columbia University, College of Physicians and Surgeons, \\ New York 10032 \\ Correspondence: sg2715@columbia.edu
}

Nuclear factor- $\mathrm{B}(\mathrm{NF}-\kappa \mathrm{B})$ consists of a family of transcription factors that play critical roles in inflammation, immunity, cell proliferation, differentiation, and survival. Inducible NF-кB activation depends on phosphorylation-induced proteosomal degradation of the inhibitor

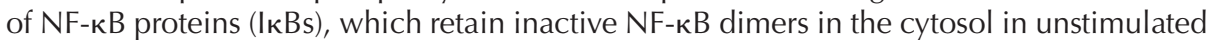
cells. The majority of the diverse signaling pathways that lead to NF-kB activation converge on the IкB kinase (IKK) complex, which is responsible for $І \kappa B$ phosphorylation and is essen-

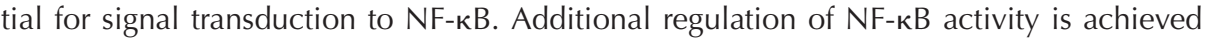
through various post-translational modifications of the core components of the NF- $\kappa B$ signaling pathways. In addition to cytosolic modifications of IKK and IкB proteins, as well as other pathway-specific mediators, the transcription factors are themselves extensively modified. Tremendous progress has been made over the last two decades in unraveling the elaborate

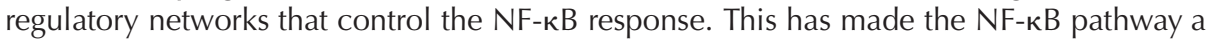
paradigm for understanding general principles of signal transduction and gene regulation.

Eollowing the identification of $\mathrm{NF}-\kappa \mathrm{B}$ - (nuclear factor- $\mathrm{kB}$ ) as a regulator of $\kappa \mathrm{B}$ light chain expression in mature $\mathrm{B}$ and plasma cells by Sen and Baltimore, inducibility of its activity in response to exogenous stimuli was demonstrated in various cell types (Sen et al. 1986b; Sen et al. 1986a). Years of intense research that followed demonstrated that $\mathrm{NF}-\kappa \mathrm{B}$ is expressed in almost all cell types and tissues, and specific NF- $\kappa \mathrm{B}$ binding sites are present in the promoters/enhancers of a large number of genes. It is now well-established that NF- $\kappa \mathrm{B}$ plays a critical role in mediating responses to a remarkable diversity of external stimuli, and thus is a pivotal element in multiple physiological and pathological processes. The progress made in the past two decades in understanding how different stimuli culminate in $\mathrm{NF}-\kappa \mathrm{B}$ activation and how NF- $\kappa \mathrm{B}$ activation is translated into a cell-type- and situation-specific response has made the NF- $\kappa \mathrm{B}$ pathway a paradigm for understanding signaling mechanisms and gene regulation. Coupled with the large number of diseases in which dysregulation of $\mathrm{NF}-\kappa \mathrm{B}$ has been implicated, the continuing interest into the regulatory mechanisms that

Editors: Louis M. Staudt and Michael Karin

Additional Perspectives on NF-кB available at www.cshperspectives.org

Copyright (C) 2009 Cold Spring Harbor Laboratory Press; all rights reserved; doi: 10.1101/cshperspect.a000034

Cite this article as Cold Spring Harb Perspect Biol 2009;1:a000034 


\section{A. Oeckinghaus and S. Ghosh}

govern the activity of this important transcription factor can be easily explained.

Because of its ability to influence expression of numerous genes, the activity of NF- $\kappa \mathrm{B}$ is tightly regulated at multiple levels. The primary mechanism for regulating NF- $\mathrm{KB}$ is through inhibitory ІкB proteins (ІкB, inhibitor of NF- $\mathrm{kB}$ ), and the kinase that phosphorylates ІкBs, namely, the ІкB kinase (IKK) complex. A number of post-translational modifications also modulate the activity of the I $\mathrm{B}$ and IKK proteins as well as NF- $\kappa B$ molecules themselves. In this article, we introduce the major players in the NF- $\mathrm{KB}$ signaling cascade and describe the key regulatory steps that control NF- $\mathrm{\kappa B}$ activity. We highlight the basic principles that underlie NF- $\mathrm{KB}$ regulation, and many of these topics are discussed in depth in other articles on the subject.

\section{NF-кB STIMULI AND кB-DEPENDENT TARGET GENES}

NF- $\kappa \mathrm{B}$ transcription factors are crucial players in an elaborate system that allows cells to adapt and respond to environmental changes, a process pivotal for survival. A large number of diverse external stimuli lead to activation of NF- $\kappa \mathrm{B}$ and the genes whose expression is regulated by NF- $\kappa \mathrm{B}$ play important and conserved roles in immune and stress responses, and impact processes such as apoptosis, proliferation, differentiation, and development.

Bacterial and viral infections (e.g., through recognition of microbial products by receptors such as the Toll-like receptors), inflammatory cytokines, and antigen receptor engagement, can all lead to activation of NF- $\mathrm{kB}$, confirming its crucial role in innate and adaptive immune responses. In addition, NF- $\mathrm{KB}$ activation can be induced upon physical (UV- or $\gamma$-irradiation), physiological (ischemia and hyperosmotic shock), or oxidative stresses (Fig. 1) (Baeuerle and Henkel 1994; Hayden et al. 2006).

Consistent with the large number of signals that activate NF- $\mathrm{kB}$, the list of target genes controlled by NF- $\mathrm{KB}$ is also extensive (Pahl 1999). Importantly, regulators of NF- $\mathrm{BB}$ such as ІкB $\alpha, \mathrm{p} 105$, or $\mathrm{A} 20$ are themselves NF-кBdependent, thereby generating auto-regulatory feedback loops in the NF- $\mathrm{\kappa B}$ response. Other

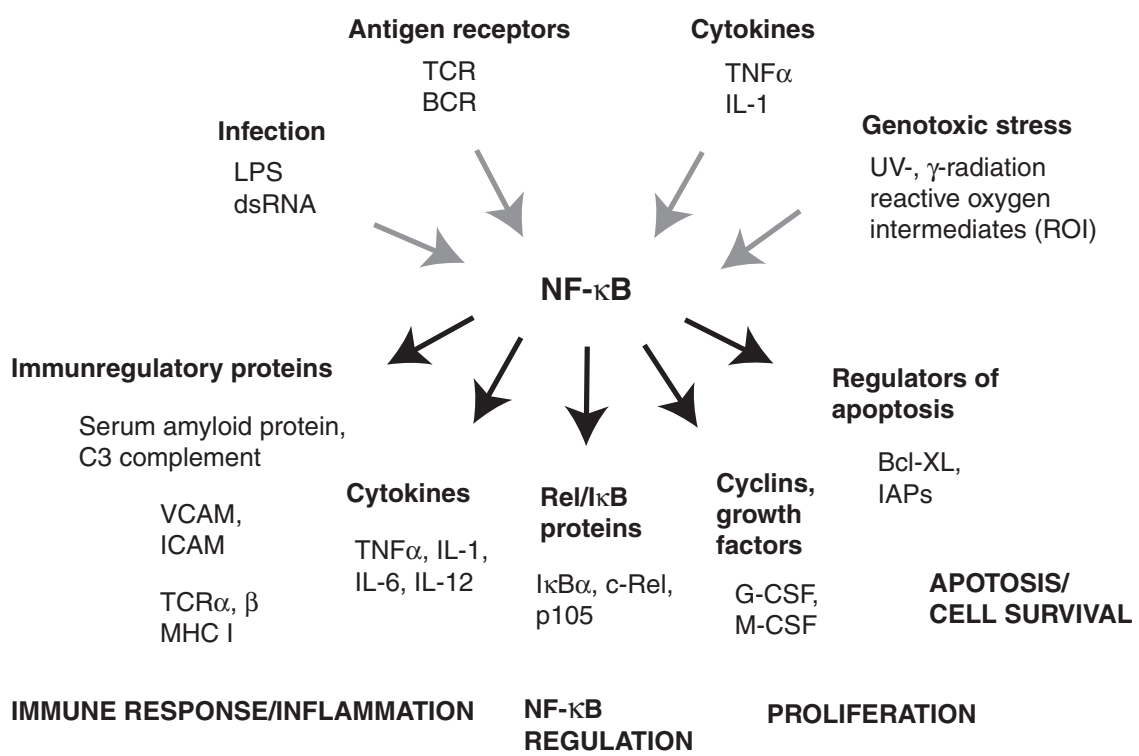

Figure 1. NF- $\kappa \mathrm{B}$ stimuli and target genes. NF- $\kappa \mathrm{B}$ acts as a central mediator of immune and inflammatory responses, and is involved in stress responses and regulation of cell proliferation and apoptosis. The respective NF- $\kappa \mathrm{B}$ target genes allow the organism to respond effectively to these environmental changes. Representative examples are given for NF- $\mathrm{kB}$ inducers and $\kappa \mathrm{B}$-dependent target genes. 
$\mathrm{NF}-\kappa \mathrm{B}$ target genes are central components of the immune response, e.g., immune receptor subunits or MHC molecules. Inflammatory processes are controlled through NF-кB-dependent transcription of cytokines, chemokines, cell adhesion molecules, factors of the complement cascade, and acute phase proteins. The list of $\kappa \mathrm{B}$-dependent target genes can be further extended to regulators of apoptosis (antiapoptotic Bcl family members and inhibitor of apoptosis proteins/IAPs) and proliferation (cyclins and growth factors), thereby substantiating its role in cell growth, proliferation, and survival (Chen and Manning 1995; Kopp and Ghosh 1995; Wissink et al. 1997). Furthermore, crucial functions of NF- $\kappa \mathrm{B}$ in embryonic development and physiology of the bone, skin, and central nervous system add to the importance of this pleiotropic transcription factor (Hayden and Ghosh 2004).

Because so many key cellular processes such as cell survival, proliferation, and immunity are regulated through $\mathrm{NF}-\kappa \mathrm{B}$-dependent transcription, it is not surprising that dysregulation of $\mathrm{NF}-\kappa \mathrm{B}$ pathways results in severe diseases such as arthritis, immunodeficiency, autoimmunity, and cancer (Courtois and Gilmore 2006).

\section{THE NF-кB TRANSCRIPTION FACTOR FAMILY}

The NF-кB transcription factor family in mammals consists of five proteins, p65 (RelA), RelB, c-Rel, p105/p50 (NF-кB1), and p100/52 $(\mathrm{NF}-\kappa \mathrm{B} 2)$ that associate with each other to form distinct transcriptionally active homoand heterodimeric complexes (Fig. 2). They all share a conserved 300 amino acid long amino-terminal Rel homology domain (RHD) (Baldwin 1996; Ghosh et al. 1998), and sequences within the RHD are required for dimerization, DNA binding, interaction with IкBs, as well as nuclear translocation. Crystal structures of p50 homo- and p50/p65 heterodimers bound to DNA revealed that the aminoterminal part of the RHD mediates specific DNA binding to the NF- $\kappa \mathrm{B}$ consensus sequence present in regulatory elements of NF- $\kappa \mathrm{B}$ target genes ( $5^{\prime}$ GGGPuNNPyPyCC-3'), whereas the carboxy-terminal part of the RHD is mainly responsible for dimerization and interaction with IкBs (Ghosh et al. 1995; Muller et al. 1995; Chen et al. 1998).

In most unstimulated cells, NF- $\kappa \mathrm{B}$ dimers are retained in an inactive form in the cytosol through their interaction with ІкB proteins. Degradation of these inhibitors upon their phosphorylation by the IкB kinase (IKK) complex leads to nuclear translocation of NF$\kappa \mathrm{B}$ and induction of transcription of target genes. Although NF- $\mathrm{B}$ activity is inducible in most cells, NF- $\kappa \mathrm{B}$ can also be detected as a constitutively active, nuclear protein in certain cell types, such as mature B cells, macrophages, neurons, and vascular smooth muscle cells, as well as a large number of tumor cells.

Through combinatorial associations, the Rel protein family members can form up to 15 different dimers. However, the physiological existence and relevance for all possible dimeric complexes has not yet been demonstrated. The p50/65 heterodimer clearly represents the most abundant of Rel dimers, being found in almost all cell types. In addition, dimeric complexes of p65/p65, p65/c-Rel, p65/p52, c-Rel/ c-Rel, p52/c-Rel, p50/c-Rel, p50/p50, RelB/ p50, and RelB/p52 have been described, some of them only in limited subsets of cells (Hayden and Ghosh 2004). RelB seems to be unique in this regard as it is only found in p50- or p52-containing complexes (Ryseck et al. 1992; Dobrzanski et al. 1994). p50/c-Rel dimers are the primary component of the constitutively active NF- $\mathrm{B}$ observed in mature B cells (Grumont et al. 1994b; Miyamoto et al. 1994). The NF-кB family of proteins can be further divided into two groups based on their transactivation potential because only p65, RelB, and c-Rel contain carboxy-terminal transactivation domains (TAD) (Fig. 2). RelB is unique in that it requires an amino-terminal leucine zipper region in addition to its TAD to be fully active (Dobrzanski et al. 1993). p50 and p52 are generated by processing of the precursor molecules p105 and p100, respectively. The amino-termini of these precursors contain the RHDs of p50 or p52, followed by a glycine rich region (GRR) and multiple 
A. Oeckinghaus and S. Ghosh
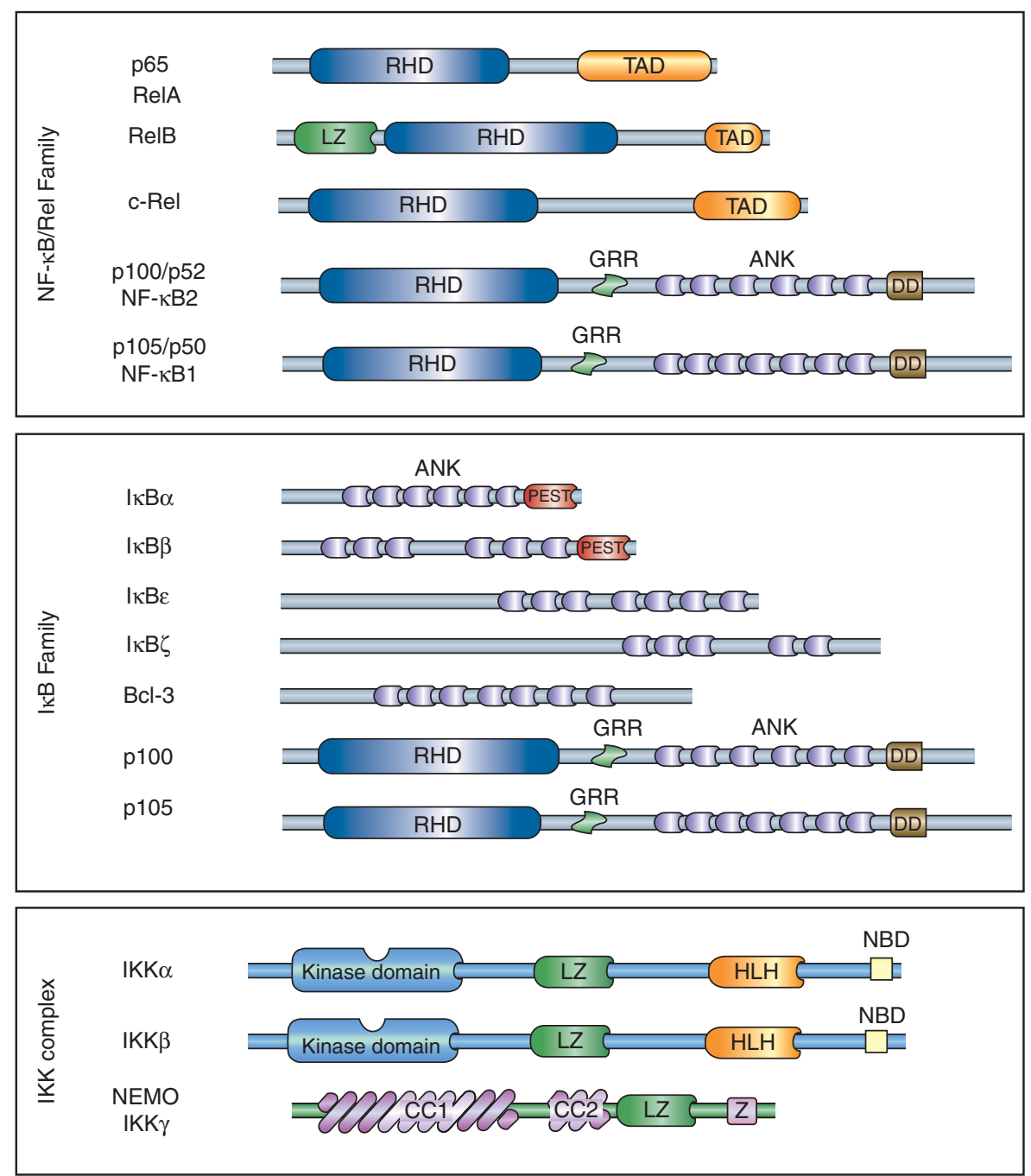

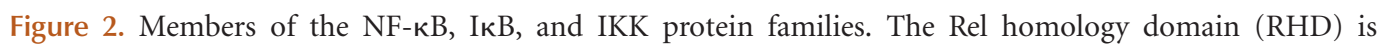

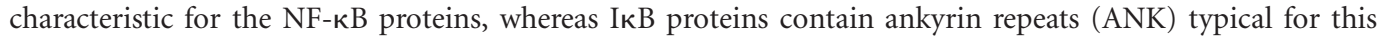
protein family. The precursor proteins p100 and p105 can therefore be assigned to and fulfill the functions of both the NF-кB and ІкB protein families. The domains that typify each protein are indicated schematically. CC, coiled-coil; DD, death domain; GRR, glycine-rich region; HLH, helix-loop-helix; IKK, IкB kinase; LZ, leucine-zipper; NBD, NEMO binding domain; PEST, proline-, glutamic acid-, serine-, and threonine-rich region; TAD, transactivation domain; $\mathrm{ZF}$, zinc finger.

copies of ankyrin repeats that are characteristic for the IкB protein family. Therefore, not all combinations of Rel dimers are transcriptionally active: DNA-bound p50 and p52 homoand heterodimers have been found to repress $\kappa \mathrm{B}$-dependent transcription, most probably by preventing trancriptionally active NF- $\mathrm{B}$ dimers from binding to $\mathrm{kB}$ sites, or through recruitment of deacetylases to promoter regions (Zhong et al. 2002). An intriguing feature of p50 and p52 is their ability to associate with atypical IкB proteins such as IкB $\zeta$ and Bcl-3, which most likely provide transcriptional activation properties. Because of their carboxyterminal ankyrin repeats, the precursors p105 and p100 can also inhibit nuclear localization 
The NF-кB Family of Transcription Factors and Its Regulation

and transcriptional activity of NF- $\mathrm{B}$ dimers that they are associated with, and hence can be classified as IкB proteins.

The specific physiological role of individual $\mathrm{NF}-\kappa \mathrm{B}$ dimers remains to be fully understood. Crystallographic structural analysis has helped delineate some of the principles that govern selection of particular $\kappa \mathrm{B}$-sites by NF- $\mathrm{B}$ dimers, and biochemical experiments revealed preferential affinities of individual dimers for particular sites in vitro. However, knockout studies demonstrated that biochemical affinity data do not fully explain the specificity of NF$\kappa \mathrm{B}$ dimers in vivo and it has become obvious that dimer selection cannot be reduced to the $\kappa \mathrm{B}$ sequence alone (Udalova et al. 2002; Hoffmann et al. 2003; Hoffmann et al. 2006; Schreiber et al. 2006; Britanova et al. 2008). The complex structures of target promoters together with the potential of particular NF$\kappa \mathrm{B}$ dimers to trigger specific protein-protein interactions at the promoter is likely to be more important as transcriptional control involves the concerted action of the transcription factor, coactivators, and corepressors in the context of nucleosomal chromatin. The $\kappa \mathrm{B}$ sequence may also affect the conformation of the bound NF- $\mathrm{B}$ dimers and thus influence their ability to recruit coactivators. Furthermore, the kinetics of NF- $\mathrm{B}$ dimer binding and release from DNA is based on the presence of sufficient IкBs, as well as the nature of post-translational modifications of NF- $\kappa B$ subunits. The combinatorial diversity of the NF- $\kappa \mathrm{B}$ dimers certainly adds to their ability to regulate distinct but overlapping sets of genes by influencing all these aspects of $\kappa \mathrm{B}$ site selection.

\section{IКB PROTEINS}

In most resting cells, the association of NF- $\kappa \mathrm{B}$ dimers with one of the prototypical I $\mathrm{B}$ proteins I $\mathrm{I} B \alpha$, ІкB $\beta$, and $І \kappa B \varepsilon$, or the precursor Rel proteins p100 and p105, determines their cytosolic localization, which makes the IкB proteins essential for signal responsiveness. In addition, expression of two atypical members of this protein family, namely Bcl-3 and
I $\kappa \zeta \zeta$, can be induced upon stimulation and regulate the activity of $\mathrm{NF}-\kappa \mathrm{B}$ dimers in the nucleus. Finally, an alternative transcript of the p105 gene, apparently only expressed in some murine lymphoid cells, has been identified and termed ІкB $\gamma$, but its physiological function remains unclear (Inoue et al. 1992; Gerondakis et al. 1993; Grumont and Gerondakis 1994a).

All ІкB proteins are characterized by the presence of five to seven ankyrin repeat motifs, which mediate their interaction with the RHD of NF- $\kappa \mathrm{B}$ proteins (Fig. 2). In general, individual I $\mathrm{B}$ proteins are thought to preferentially associate with a particular subset of NF-кB dimers, however surprisingly little experimental evidence concerning this important subject exists. I $\kappa \mathrm{B} \alpha$ and $\mathrm{I} \kappa \mathrm{B} \beta$ are primarily believed to inhibit c-Rel and p65-containing complexes, with IкB $\alpha$ having a higher affinity for p65:p50 than for p65:p65 complexes (Malek et al. 2003). RelB exclusively binds p100, whereas $\mathrm{Bcl}-3$ and $\mathrm{I} \kappa \mathrm{B} \zeta$ preferentially associate with homodimers of p50 and p52 (Hoffmann et al. 2006).

\section{The Canonical I $\mathrm{kBs}$}

The amino-terminal signal responsive regions (SRR) of the typical IкB proteins IкB $\alpha$, ІкB $\beta$, and $\mathrm{I} \kappa \mathrm{B} \varepsilon$ contain conserved serine residues (e.g., Ser32 and Ser36 in IкB $\alpha$ ) that are targeted by the IKK $\beta$ subunit of the IKK complex in the course of canonical signaling to NF- $\kappa \mathrm{B}$ (see also paragraph: The IKK complex). Phosphorylated IкB proteins are then modified with K48-linked ubiquitin chains by ubiquitin ligases of the SCF or SCRF (Skp1-Culin-Roc1/ Rbx1/Hrt-1-F-box) family, upon recognition of the $\mathrm{DS}^{\mathrm{P}} \mathrm{GXXS}^{\mathrm{P}}$ motif of phosphorylated I $\mathrm{B}$ proteins through their receptor subunit $\beta$-TRCP ( $\beta$-tranducin repeat containing protein) (Yaron et al. 1998; Fuchs et al. 1999; Hatakeyama et al. 1999; Kroll et al. 1999; Wu and Ghosh 1999). Ubiquitination of ІкBs ultimately results in their degradation by the proteasome.

$\mathrm{I} \kappa \mathrm{B} \alpha$ is the best-studied member of the IкB family of proteins and displays all defining 
characteristics of an NF- $\mathrm{B}$ inhibitor. The canonical p65/p50 heterodimer is primarily associated with $\mathrm{I} \kappa \mathrm{B} \alpha$ and rapid, stimulusinduced degradation of $\mathrm{I} \kappa \mathrm{B} \alpha$ is critical for nuclear translocation and DNA binding of NF-кB p65/p50. The traditional model of ІкB function posits that $\mathrm{I} \kappa \mathrm{B}$ proteins sequester NF-кB in the cytosol; however, the actual situation is more complex. Crystallographic struc-

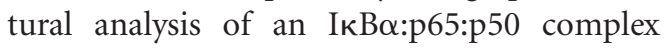
revealed that the $\mathrm{I} \kappa \mathrm{B} \alpha$ molecule masks only the nuclear localization sequence (NLS) of p65, whereas the NLS of p50 remains accessible (Huxford et al. 1998; Jacobs and Harrison 1998). This exposed NLS together with the nuclear export sequence (NES) present in $\mathrm{I} \kappa \mathrm{B} \alpha$ leads to constant shuttling of $\mathrm{I} \kappa \mathrm{B} \alpha$ : NF- $\kappa \mathrm{B}$ complexes between the nucleus and cytosol, despite a steady-state localization that appears to be exclusively cytosolic. Degradation of I $\mathrm{B} \alpha$ shifts this dynamic equilibrium because it eliminates contribution of the NES in Iк $\mathrm{B} \alpha$ and exposes the previously masked NLS of $\mathrm{p} 65$. As active NF- $\mathrm{B}$ promotes $\mathrm{I} \kappa \mathrm{B} \alpha$ expression, an important negative feedback regulatory mechanism is generated that critically influences the duration of the NF- $\mathrm{B}$ response. Consistent with such a role, termination of the $\mathrm{NF}-\kappa \mathrm{B}$ response upon $\mathrm{TNF} \alpha$ stimulation is notably delayed in the case of I $\kappa \mathrm{B} \alpha$ deficiency (Klement et al. 1996).

The roles of the other ІкB family members are less well established. Although IкB $\beta$ shows NF- $\kappa \mathrm{B}$ binding specificity similar to $\mathrm{I} \kappa \mathrm{B} \alpha$, it also possesses a number of unique properties. In contrast to $\mathrm{I} \kappa \mathrm{B} \alpha$, I $\kappa \mathrm{B} \beta \mathrm{NF}-\kappa \mathrm{B}$ complexes do not undergo nuclear-cytoplasmic shuttling (Tam and Sen 2001) and IкB $\beta$ can associate with NF- $\kappa \mathrm{B}$ complexes bound to DNA, suggesting a possible regulatory function in the nucleus (Thompson et al. 1995; Suyang et al. 1996). Even though IкB $\beta$ is degraded and resynthesized in a stimulus-dependent manner-although with considerably delayed kinetics compared to IкB $\alpha$-ІкВ $\beta$ deletion does not affect the kinetics of $\mathrm{NF}-\kappa \mathrm{B}$ responses significantly (Hoffmann et al. 2002). Surprisingly, knocking in of IкB $\beta$ to replace $\mathrm{I} \kappa \mathrm{B} \alpha$, thereby placing I $\mathrm{B} \beta$ expression under the regulation of the
I $\kappa \mathrm{B} \alpha$ promoter, leads to normal kinetics of $\mathrm{NF}-\kappa \mathrm{B}$ activation and termination despite the fact that IкB $\beta$ normally does not function in the early dampening of the NF- $\kappa \mathrm{B}$ response (Cheng et al. 1998). This suggests that the functional characteristics of the different canonical I $\mathrm{Bs}$ are at least in part caused by temporal distinctions in their resynthesis based on the specific transcriptional regulation of their promoters (Hoffmann et al. 2002).

Similar to IкB $\beta$, I $\mathrm{B} \varepsilon \varepsilon$ is also degraded and resynthesized in response to $\mathrm{NF}-\kappa \mathrm{B}$ signaling with significantly delayed kinetics (Kearns et al. 2006). Besides, IкBe expression and function seem to be limited to cells of the hematopoetic lineage, reinforcing the hypothesis that distinct I $\kappa$ Bs exert unique roles in NF- $\kappa \mathrm{B}$ responses in different cellular scenarios.

\section{The Precursor $\mathbb{I}_{\kappa} \mathrm{Bs}$}

The precursor proteins p100 and p105 are exceptional in their ability to function as Rel protein inhibitors, because they can dimerize with other NF- $\mathrm{B}$ molecules via their RHDs, whereas their carboxy-terminal ankyrin repeats serve the function of IкB proteins (Rice et al. 1992; Naumann et al. 1993; Solan et al. 2002). Although their overall sequence and organization is similar, generation of p50 and p52 from their respective precursors occurs through distinct processing mechanisms. p105 is constitutively processed, resulting in a preset ratio of p105 and p50 containing Rel dimers in each cell. This constitutive processing has been suggested to occur co- or post-translationally (Lin et al. 1998; Moorthy et al. 2006) and depends on a GRR located carboxy-terminal to the RHD that serves as termination signal for the proteosomal proteolysis (Lin and Ghosh 1996). However, p105 can, like IкB $\alpha$, also undergo complete degradation upon phosphorylation of carboxy-terminal serine residues by IKK $\beta$, a process that is favored when p105 is bound to other NF-кB subunits (Harhaj et al. 1996; Heissmeyer et al. 1999; Cohen et al. 2001; Cohen et al. 2004; Perkins 2006). Interestingly, this event has been suggested to be independent of ubiquitination (Moorthy et al. 2006). 
p100 processing represents a predominantly stimulus-dependent event that defines the noncanonical NF- $\kappa \mathrm{B}$ activation pathway (see also paragraph: The IKK complex). It is regulated through phosphorylation of $\mathrm{p} 100$ by the IKK $\alpha$ subunit of the IKK complex, which results in ubiquitination and subsequent partial degradation of p100 by the proteasome, releasing transcriptionally active p50/RelB complexes (Senftleben et al. 2001). However, p100 can also regulate p65-containing complexes downstream of IKK $\alpha$ and limit p65-dependent responses in $\mathrm{T}$ cells in a negative feedback loop similar to I $\mathrm{B} \alpha$, thereby acting as an inhibitor in canonical signaling pathways (Ishimaru et al. 2006; Basak et al. 2007). Constitutive processing of p100 has only been described to occur at a low level in certain cell types (Heusch et al. 1999). The ability of p100 to regulate RelB is of particular importance, as RelBcontaining dimers exclusively associate with p100 and require p100 binding for stabilization (Solan et al. 2002). Therefore, p100 is able to affect NF- $\kappa \mathrm{B}$ transcriptional responses at a level that extends beyond its role as an IкB protein.

\section{The Atypical ІКBs}

The role of the atypical $\mathrm{I} \kappa \mathrm{B}$ protein $\mathrm{Bcl} 3$ in $\mathrm{NF}-\kappa \mathrm{B}$ signaling is not fully understood and its mechanism of action is still unclear. $\mathrm{Bcl} 3$ contains a TAD and is found primarily in the nucleus, where it associates with p50 and p52 homo- or heterodimers. Bcl3 has been suggested to provide transcriptional activation function on otherwise repressive p50 or p52 homodimers (Bours et al. 1993). Furthermore, $\mathrm{Bcl} 3$ may remove repressive dimers from promoters, thereby allowing transcriptionally active p65/50 to access and facilitate transcription in an indirect manner through release of repression (Wulczyn et al. 1992; Hayden and Ghosh 2004; Perkins 2006). Conversely, induction of $\mathrm{Bcl} 3$ expression has been shown to inhibit subsequent NF- $\mathrm{B}$ activation. In such a model, $\mathrm{Bcl} 3$ may stabilize repressing dimers at $\kappa \mathrm{B}$ sites, thereby preventing access of TAD containing $\mathrm{NF}-\kappa \mathrm{B}$ dimers and consequent transcription (Wessells et al. 2004; Carmody et al. 2007). The potential of $\mathrm{Bcl} 3$ to either promote or impede transcription has been shown to depend to some extent on different post-translational modifications (Nolan et al. 1993; Bundy and McKeithan 1997; Massoumi et al. 2006).

Within the IкB family, IкB $\zeta$ is most similar to $\mathrm{Bcl} 3$. It is not constitutively expressed, but induced upon engagement of IL-1 and TLR4 receptors and is localized to the nucleus (Yamazaki et al. 2005). For the most part, ІкB $\zeta$ associates with p50 homodimers. Expression of a subset of NF- $\mathrm{KB}$ target genes, including IL-6, is not induced in $\mathrm{I} \kappa \mathrm{B} \zeta$-deficient cells upon IL-1 or LPS stimulation. I $\mathrm{I} B \zeta$ is hypothesized to act as a coactivator of p50 homodimers even though ІкB $\zeta$ does not contain an apparent TAD (Yamamoto et al. 2004). ІкBל has also been suggested to negatively regulate p65-containing complexes and may thus also be able to selectively activate or impede specific NF- $\mathrm{KB}$ activity (Yamamoto et al. 2004; Motoyama et al. 2005).

It is obvious that our perception of $\mathrm{I} \kappa \mathrm{B}$ proteins has changed significantly over the years from relatively simple inhibitory molecules to complex regulators of NF- $\mathrm{B}$-driven gene expression. As described previously, I $\kappa$ s can influence the makeup of cellular $\mathrm{NF}-\kappa \mathrm{B}$ through specific stabilization of unstable dimers, stabilize DNA-bound dimers, thereby repressing or prolonging transcriptional responses, or even act as transcriptional coactivators. Therefore, it is probably more appropriate to consider IкBs as multifaceted NF- $\kappa \mathrm{B}$ regulators.

\section{THE IKK COMPLEX: CANONICAL AND NON-CANONICAL SIGNALING TO NF-кB}

The first biochemical experiments assigned the cytosolic IкB kinase activity to a large protein complex of 700-900 kDa capable of specifically phosphorylating IкB $\alpha$ on serines 32 and 36 . Purification of this complex revealed the presence of two catalytically active kinases, $\mathrm{IKK} \alpha$ and IKK $\beta$, and the regulatory subunit IKK $\gamma$ (NEMO) (Chen et al. 1996; Mercurio et al. 1997; Woronicz et al. 1997; Zandi et al. 
1997). IKK $\alpha$ and IKK $\beta$ are ubiquitously expressed and contain an amino-terminal kinase domain, a leucine zipper, and a carboxyterminal helix-loop-helix domain (HLH) (Fig. 2). The leucine zipper is responsible for dimerization of the kinases and mutations in this region render the kinases inactive, whereas the HLH is dispensable for dimerization, but essential for optimal kinase activity (Zandi et al. 1998). The carboxy-terminal portions of IKK $\alpha$ and $-\beta$ are critical for their interaction with the regulatory subunit IKK $\gamma$, which is mediated by a hexapeptide sequence (LDWSWL) on IKKs termed the NEMO binding domain (NBD) (May et al. 2000; May et al. 2002). Activation of the IKK complex is dependent on the phosphorylation of two serines in the sequence motif SLCTS of the T-loop regions in at least one of the ІкB kinases (Mercurio et al. 1997; Ling et al. 1998). Whether these phosphorylation events occur through trans-autophosphorylation or through phosphorylation by an upstream kinase continues to be debated (Hayden and Ghosh 2004; Scheidereit 2006).

The physiological significance of IKK $\alpha$ and IKK $\beta$ has been analyzed extensively in knockout mice. These studies have revealed two general types of signal propagation pathways to NF- $\kappa \mathrm{B}$ activation, which are distinct in respect to the inducing stimuli, the IKK subunits involved, and the NF- $\kappa \mathrm{B} / \mathrm{I} \kappa \mathrm{B}$ substrates targeted (Fig. 3). In the canonical NF- $\mathrm{B}$ pathway, which is induced by inflammatory cytokines, pathogen-associated molecules, and antigen receptors, IKK $\beta$ is both necessary and sufficient to phosphorylate $\mathrm{I} \kappa \mathrm{B} \alpha$ or $\mathrm{I} \kappa \mathrm{B} \beta$ in an IKK $\gamma$-dependent manner. Thus, IKK $\beta$ deficient mice exhibit embryonic lethality caused by severe liver apoptosis because of defective TNF signaling to NF- $\kappa$ B in the developing liver (Beg et al. 1995; Li et al. 1999a; Li et al. 1999b). Congruently, IKK $\beta$-deficient cells were shown to be unable to activate NF- $\kappa$ B upon stimulation with proinflammatory cytokines such as TNF $\alpha$ or interleukin-1 (IL-1) (Li et al. 1999a; Li et al. 1999b). The role of IKK $\alpha$ in canonical NF-кB signaling remains unclear; however, more recent studies have established a role for IKK $\alpha$ in regulating gene expression by modifying the phosphorylation status of histones and p65 (Anest et al. 2003; Yamamoto et al. 2003; Chen and Greene 2004).

In contrast to the canonical pathway, the non-canonical pathway that is induced by specific members of the TNF cytokine family, such as BAFF, lymphotoxin- $\beta$, or CD40 ligand relies on $\mathrm{IKK} \alpha$, but not IKK $\beta$ or IKK $\gamma$. IKK $\alpha$ is believed to selectively phosphorylate p100 associated with RelB (Senftleben et al. 2001; Scheidereit 2006). Although the upstream signal propagation events are poorly understood, IKK $\alpha$ clearly requires activation of NIK (NF-кB-inducing kinase), which seems to function as both an IKK $\alpha$-activating kinase as well as a scaffold linking IKK $\alpha$ and p100 (Xiao et al. 2004). Phosphorylation of p100 entails recruitment of SCF ${ }^{\beta T r C P}$ and subsequent polyubiquitination of Lys855, which is situated in a peptide sequence homologous to that targeted in I $\mathrm{I} B \alpha$ (Fong and Sun 2002; Amir et al. 2004). Similar to p105 processing, the GRR of p100 is required for partial processing to generate $\mathrm{p} 52$. In addition to non-canonical signaling to NF- $\kappa \mathrm{B}, \mathrm{IKK} \alpha$ regulates developmental processes that are both dependent, as well as independent, of NF- $\mathrm{\kappa B}$-induced gene transcription (Sil et al. 2004).

\section{POST-TRANSLATIONAL MODIFICATIONS OF NF-KB}

Given the wide range of biological processes that are affected by NF- $\mathrm{kB}$, and the disastrous consequences of dysregulated NF- $\kappa \mathrm{B}$ signaling, intricate and highly regulated mechanisms exist for controlling NF- $\kappa \mathrm{B}$ activity. These added layers of regulation involve a variety of posttranslational modifications of various core components of this signaling pathway, thereby influencing NF- $\kappa \mathrm{B}$ activity at multiple levels. The critical phosphorylation and ubiquitination events of I $\mathrm{KB}$ proteins and the IKK complex have been described previously. In addition, the NF- $\mathrm{B}$ subunits themselves are subject to a wide range of regulatory 
The NF-кB Family of Transcription Factors and Its Regulation

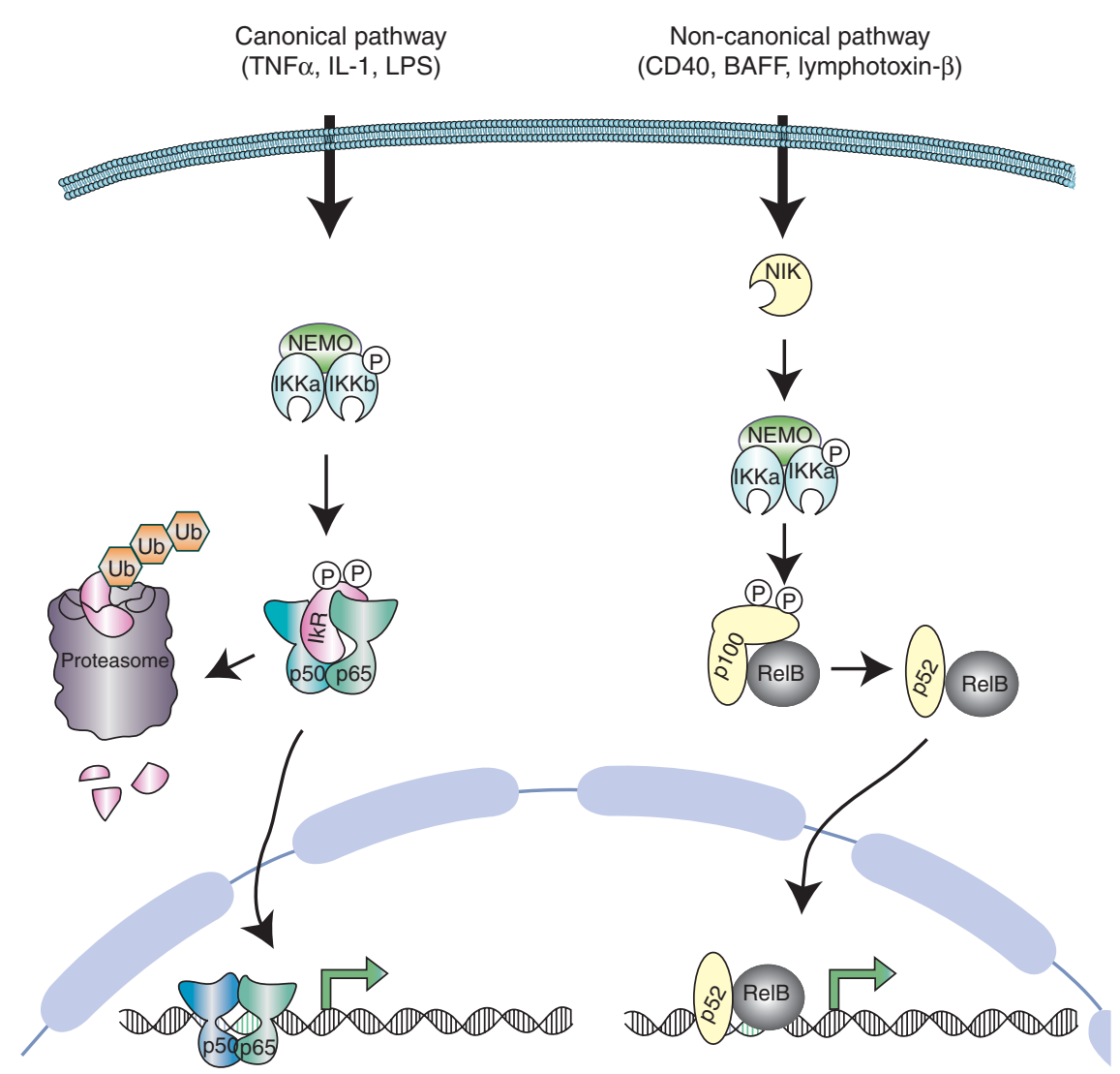

Figure 3. Canonical and non-canonical signaling to NF-кB. The canonical pathway is, e.g., induced by TNF $\alpha$, IL-1, or LPS and uses a large variety of signaling adaptors to engage IKK activity. Phosphorylation of serine

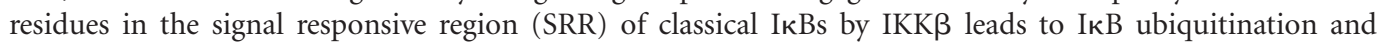
subsequent proteosomal degradation. This results in release of the NF- $\kappa \mathrm{B}$ dimer, which can then translocate to the nucleus and induce transcription of target genes. The non-canonical pathway depends on NIK (NF$\kappa \mathrm{B}$-inducing kinase) induced activation of IKK $\alpha$. IKK $\alpha$ phosphorylates the p100 NF- $\mathrm{B}$ subunit, which leads to proteosomal processing of p100 to p52. This results in the activation of p52-RelB dimers, which target specific $\kappa \mathrm{B}$ elements.

protein modifications, including phosphorylation, ubiquitination, or acetylation (Perkins 2006). Some of these modifications also represent important means for cross talk between different signaling pathways (Perkins 2007).

Importantly, degradation of IкBs and nuclear translocation of the NF- $\mathrm{BB}$ dimers alone are not sufficient in eliciting a maximal NF- $\mathrm{B}$ response, which has been shown to also critically depend on protein modifications of NF-кB subunits. Post-translational modifications of p65 have been most thoroughly investigated in this context. Phosphorylation by protein kinase $A$ (PKA) was the first modification of p65 to be recognized and has since been demonstrated to be critical for p65driven gene expression of many but not all target genes (Naumann and Scheidereit 1994; Neumann et al. 1995; Chen and Greene 2004). The catalytic subunit of PKA (PKAc) exists in

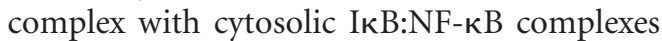
and is activated upon IкB degradation to phosphorylate Ser276 of p65. p50 and c-Rel are also modified by PKAc at equivalent sites to RelA (Perkins 2006). In p65, Ser 276 phosphorylation is thought to break an intramolecular interaction between the carboxy-terminal part of the protein and the RHD, thereby facilitating 
DNA binding and enabling interaction with the transcriptional coactivators p300 and CBP (CREB-binding protein) (Zhong et al. 1998; Zhong et al. 2002). In addition to PKA, MSK1 and MSK2 (mitogen- and stress-activated protein kinase) have been shown to target Ser276, and in doing so possibly mediating cross talk with the ERK and p38 MAPK pathways (Vermeulen et al. 2003; Perkins 2006). Several additional phosphorylation events have been described but the physiological consequences in most cases remain less clear. Ser536 within the TAD of p65 seems to be a phosphorylation site that is targeted by several kinases, including IKK $\beta$. Numerous effects have been ascribed to this modification, including regulation of p65 nuclear localization and $\mathrm{CBP} / \mathrm{p} 300$ interaction (Chen et al. 2005; Perkins 2006). CK2 has been shown to inducibly modify Ser529; however, it remains unclear whether this phosphorylation affects p65 transcriptional activity (Wang et al. 2000). Ser311 can be phosphorylated by the atypical protein kinase PKC $\zeta$ in response to TNF stimulation, which has also been demonstrated to positively influence p65:CBP interaction (Duran et al. 2003). Interestingly, of the four phosphorylation sites mentioned above, two are found in the RHD (Ser276 and Ser311), whereas the other two are located within the TAD (Ser529 and Ser 536).

The diversity of the p65 phosphorylation sites detected so far suggests that possibly even more modification sites will be discovered in the future, in particular in other NF- $\mathrm{B}$ subunits. It is likely that these modifications would serve to fine-tune NF- $\kappa \mathrm{B}$ transcriptional activity, e.g., in determining target-gene specificity and timing of gene expression, rather than acting as simple on-off switches.

p65 can also be inducibly acetylated at different sites (Lys122, 123, 218, 221, and 310) with variable effects on its activity, probably by the action of $\mathrm{CBP} / \mathrm{p} 300$ and associated histone acetyltransferases (HAT). While acetylation of lysines 218, 221, and 310 has been shown to promote p65 transactivation, acetylated lysines 122 and 123 act in an inhibitory manner. Acetylation at Lys310, promoted by phosphorylation of Ser276, has been shown to augment transcriptional activity without affecting DNA or ІкB binding, presumably through generating a binding site for a coactivator protein. In contrast, acetylated Lys 221 impedes association with Iк $\mathrm{B} \alpha$, thereby enhancing DNA binding (Chen et al. 2002; Chen and Greene 2004). Different histone deacetylases (HDAC) such as HDAC-3 and SIRT1 have been implicated in removing p65 acetylations (Chen and Greene 2004; Yeung et al. 2004).

\section{TERMINATION OF THE NF-кB RESPONSE}

Our knowledge about the mechanisms leading to NF- $\mathrm{BB}$ activation far exceeds what we know about the regulatory mechanisms that determine its inactivation. The best studied and well accepted mechanism for termination of the NF- $\kappa \mathrm{B}$ response involves the resynthesis of I $\mathrm{B}$ proteins induced by activated $\mathrm{NF}-\kappa \mathrm{B}$ (Pahl 1999). Newly synthesized ІкB $\alpha$ can enter the nucleus, remove $\mathrm{NF}-\kappa \mathrm{B}$ from the DNA, and relocalize it to the cytosol (Hayden and Ghosh 2004). Also, the precursors p105 and p100, as well as c-Rel and RelB, are NF- $\mathrm{B}$ inducible genes, and hence the composition of NF- $\kappa \mathrm{B}$ complexes in a cell can vary over time. Significant progress has also been made in understanding how negative regulators influence signaling upstream of the IKK complex (Hayden and Ghosh 2004; Krappmann and Scheidereit 2005; Hacker and Karin 2006). In the recent years, additional inhibitory mechanisms have been identified that function later in the pathway and directly affect the active, DNA-bound NF-кB. These include posttranslational modifications of $\mathrm{NF}-\mathrm{\kappa B}$ subunits and have been shown to participate in shutting off the NF- $\kappa \mathrm{B}$ response by altering cofactor binding or mediating displacement and degradation of NF- $\kappa \mathrm{B}$ dimers. Because acetylation of p65 has been demonstrated to negatively impact its DNA-binding affinity (Kiernan et al. 2003), regulation of p65 association with HATs and HDACs influences termination of the NF- $\kappa \mathrm{B}$ response (Ghosh and Hayden 2008). An alternative scenario involves ubiquitin-dependent proteosomal degradation 
of promoter-bound p65, facilitated by the ubiquitin ligase SOCS-1 (Ryo et al. 2003; Saccani et al. 2004). In parallel, the nuclear ubiquitin ligase PDLIM2 has been shown to target p65 for ubiquitination and proteasomal degradation, as well as to transport p65 to promyelocytic leukemia (PML) nuclear bodies, thereby supporting transcriptional silencing (Tanaka et al. 2007). In addition, IKK $\alpha$ has been demonstrated to promote p65 and c-Rel turnover and removal from proinflammatory gene promoters in macrophages (Lawrence et al. 2005). Finally, NF- $\kappa \mathrm{B}$ subunits have been shown to be inhibited by oxidation and alkylation of a redoxsensitive cysteine located in the DNA-binding loop (Perkins 2006). This list is far from being complete and it seems that we have just begun to understand the complex network of modifications regulating $\mathrm{NF}-\kappa \mathrm{B}$ transcriptional activity in the nucleus. As a detailed knowledge of these mechanisms is crucial for our understanding of the function of $\mathrm{NF}-\kappa \mathrm{B}$, this area of investigation is likely to continue to attract significant attention in the future.

\section{CONCLUSIONS}

The transcription factors of the NF- $\mathrm{B}$ family control the expression of a large number of target genes in response to changes in the environment, thereby helping to orchestrate inflammatory and immune responses. As aberrant NF- $\kappa \mathrm{B}$ activation underlies various disease states, precise activation and termination of NF- $\kappa \mathrm{B}$ is ensured by multiple regulatory processes. It is fair to say that the I $\kappa \mathrm{B}$ proteins represent one of the primary means of NF- $\mathrm{KB}$ regulation, although their versatile effects on $\mathrm{NF}-\kappa \mathrm{B}$ activity make them more complex than simple inhibitory proteins. A diverse array of post-translational modifications of IKK, ІкB, and NF- $\kappa \mathrm{B}$ proteins provides the means to finetune the NF- $\kappa B$ response at multiple levels. Tremendous progress has been made in understanding the regulatory mechanisms shaping the NF- $\kappa$ B response, yet it is striking how much still remains to be discovered. Because of the well-characterized links between NF- $\mathrm{B}$ and diseases like cancer or arthritis, unraveling the complexity of NF- $\kappa \mathrm{B}$ regulation remains a major goal to help act on specific steps of the NF- $\kappa$ B pathway, thereby avoiding the risk of harmful side effects that could result from general inhibition of NF- $\mathrm{B}$.

\section{REFERENCES}

Amir RE, Haecker H, Karin M, Ciechanover A. 2004. Mechanism of processing of the NF- $\mathrm{B} 2 \mathrm{p} 100$ precursor: Identification of the specific polyubiquitin chainanchoring lysine residue and analysis of the role of NEDD8-modification on the $\operatorname{SCF}(\beta-\operatorname{TrCP})$ ubiquitin ligase. Oncogene 23: 2540-2547.

Anest V, Hanson JL, Cogswell PC, Steinbrecher KA, Strahl BD, Baldwin AS. 2003. A nucleosomal function for I $\mathrm{kB}$ kinase- $\alpha$ in NF- $\kappa$ B-dependent gene expression. Nature 423: 659-663.

Baeuerle PA, Henkel T. 1994. Function and activation of NF-к B in the immune system. Annu Rev Immunol 12: 141-179.

Baldwin AS Jr. 1996. The NF-к B and I к B proteins: New discoveries and insights. Annu Rev Immunol 14: 649-683.

Basak S, Kim H, Kearns JD, Tergaonkar V, O’Dea E, Werner SL, Benedict CA, Ware CF, Ghosh G, Verma IM, et al.

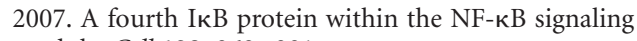
module. Cell 128: 369-381.

Beg AA, Sha WC, Bronson RT, Ghosh S, Baltimore D. 1995. Embryonic lethality and liver degeneration in mice lacking the RelA component of NF-к B. Nature 376: $167-170$.

Bours V, Franzoso G, Azarenko V, Park S, Kanno T, Brown K, Siebenlist U. 1993. The oncoprotein Bcl-3 directly transactivates through $\kappa \mathrm{B}$ motifs via association with DNA-binding p50B homodimers. Cell 72: 729-739.

Britanova LV, Makeev VJ, Kuprash DV. 2008. In vitro selection of optimal RelB/p52 DNA-binding motifs. Biochem Biophys Res Commun 365: 583-588.

Bundy DL, McKeithan TW. 1997. Diverse effects of BCL3 phosphorylation on its modulation of NF- $\mathrm{B}$ p52 homodimer binding to DNA. J Biol Chem 272: 33132-33139.

Carmody RJ, Ruan Q, Palmer S, Hilliard B, Chen YH. 2007. Negative regulation of toll-like receptor signaling by NF-кB p50 ubiquitination blockade. Science 317: $675-678$.

Chen CC, Manning AM. 1995. Transcriptional regulation of endothelial cell adhesion molecules: A dominant role for NF-к B. Agents Actions Suppl 47: 135-141.

Chen LF, Greene WC. 2004. Shaping the nuclear action of NF-кB. Nat Rev Mol Cell Biol 5: 392-401.

Chen LF, Mu Y, Greene WC. 2002. Acetylation of RelA at discrete sites regulates distinct nuclear functions of NF- $\mathrm{\kappa B}$. EMBO J 21: 6539-6548.

Chen ZJ, Parent L, Maniatis T. 1996. Site-specific phosphorylation of IкB by a novel ubiquitination-dependent protein kinase activity. Cell 84: 853-862. 
Chen FE, Huang DB, Chen YQ, Ghosh G. 1998. Crystal structure of p50/p65 heterodimer of transcription factor NF-кB bound to DNA. Nature 391: 410-413.

Chen LF, Williams SA, Mu Y, Nakano H, Duerr JM, Buckbinder L, Greene WC. 2005. NF-кB RelA phosphorylation regulates RelA acetylation. Mol Cell Biol 25: 7966-7975.

Cheng JD, Ryseck RP, Attar RM, Dambach D, Bravo R. 1998. Functional redundancy of the nuclear factor $\kappa \mathrm{B}$ inhibitors I к B and I к B $\beta$. J Exp Med 188: 1055-1062.

Cohen S, Orian A, Ciechanover A. 2001. Processing of p105 is inhibited by docking of p50 active subunits to the ankyrin repeat domain, and inhibition is alleviated by signaling via the carboxyl-terminal phosphorylation/ ubiquitin-ligase binding domain. J Biol Chem 276: 26769-26776.

Cohen S, Achbert-Weiner H, Ciechanover A. 2004. Dual effects of IкB kinase $\beta$-mediated phosphorylation on p105 Fate: $\operatorname{SCF}(\beta-\operatorname{TrCP})$-dependent degradation and SCF $(\beta-\operatorname{TrCP})$-independent processing. Mol Cell Biol 24: 475-486.

Courtois G, Gilmore TD. 2006. Mutations in the NF-кB signaling pathway: Implications for human disease. Oncogene 25: 6831-6843.

Dobrzanski P, Ryseck RP, Bravo R. 1993. Both N- and C-terminal domains of RelB are required for full transactivation: Role of the $\mathrm{N}$-terminal leucine zipper-like motif. Mol Cell Biol 13: 1572-1582.

Dobrzanski P, Ryseck RP, Bravo R. 1994. Differential interactions of Rel-NF- $\kappa$ B complexes with I $\kappa$ B determine pools of constitutive and inducible NF- $\mathrm{B}$ activity. EMBO J 13: 4608-4616.

Duran A, Diaz-Meco MT, Moscat J. 2003. Essential role of RelA Ser311 phosphorylation by zetaPKC in NF-кB transcriptional activation. EMBO J 22: 3910-3918.

Fong A, Sun SC. 2002. Genetic evidence for the essential role of $\beta$-transducin repeat-containing protein in the inducible processing of NF-к B2/p100. J Biol Chem 277: 22111-22114.

Fuchs SY, Chen A, Xiong Y, Pan ZQ, Ronai Z. 1999. HOS, a human homolog of Slimb, forms an SCF complex with Skp1 and Cullin1 and targets the phosphorylationdependent degradation of IкB and $\beta$-catenin. Oncogene 18: 2039-2046.

Gerondakis S, Morrice N, Richardson IB, Wettenhall R, Fecondo J, Grumont RJ. 1993. The activity of a 70 kilodalton I $\kappa$ B molecule identical to the carboxyl terminus of the p105 NF- $\mathrm{B}$ precursor is modulated by protein kinase A. Cell Growth Differ 4: 617-627.

Ghosh S, Hayden MS. 2008. New regulators of NF-кB in inflammation. Nat Rev Immunol 8: 837-848.

Ghosh S, May MJ, Kopp EB. 1998. NF-к B and Rel proteins: Evolutionarily conserved mediators of immune responses. Annu Rev Immunol 16: 225-260.

Ghosh G, van Duyne G, Ghosh S, Sigler PB. 1995. Structure of NF-к B p50 homodimer bound to a $\kappa$ B site. Nature 373: $303-310$.

Grumont RJ, Gerondakis S. 1994a. Alternative splicing of RNA transcripts encoded by the murine p105 NF- $\mathrm{B}$ gene generates I $\kappa \mathrm{B} \gamma$ isoforms with different inhibitory activities. Proc Natl Acad Sci 91: 4367-4371.
Grumont RJ, Gerondakis S. 1994b. The subunit composition of NF- $\mathrm{B}$ complexes changes during B-cell development. Cell Growth Differ 5: 1321-1331.

Hacker H, Karin M. 2006. Regulation and function of IKK and IKK-related kinases. Sci STKE 2006: re13.

Harhaj EW, Maggirwar SB, Sun SC. 1996. Inhibition of p105 processing by NF- $\mathrm{\kappa B}$ proteins in transiently transfected cells. Oncogene 12: 2385-2392.

Hatakeyama S, Kitagawa M, Nakayama K, Shirane M, Matsumoto $M$, Hattori $K$, Higashi $H$, Nakano $H$, Okumura K, Onoe K, et al. 1999. Ubiquitin-dependent degradation of $\mathrm{I \kappa B}$ is mediated by a ubiquitin ligase Skp1/Cul 1/F-box protein FWD1. Proc Natl Acad Sci 96: $3859-3863$.

Hayden MS, Ghosh S. 2004. Signaling to NF-кB. Genes Dev 18: $2195-2224$.

Hayden MS, West AP, Ghosh S. 2006. NF-кB and the immune response. Oncogene 25: 6758-6780.

Heissmeyer V, Krappmann D, Wulczyn FG, Scheidereit C. 1999. NF-кB p105 is a target of IкB kinases and controls signal induction of Bcl-3-p50 complexes. EMBO J 18: 4766-4778.

Heusch M, Lin L, Geleziunas R, Greene WC. 1999. The generation of nfkb2 p52: Mechanism and efficiency. Oncogene 18: 6201-6208.

Hoffmann A, Leung TH, Baltimore D. 2003. Genetic analysis of NF- $\mathrm{kB} /$ Rel transcription factors defines functional specificities. EMBO J 22: 5530-5539.

Hoffmann A, Natoli G, Ghosh G. 2006. Transcriptional regulation via the NF- $\mathrm{kB}$ signaling module. Oncogene 25: 6706-6716.

Hoffmann A, Levchenko A, Scott ML, Baltimore D. 2002. The IкB-NF-кB signaling module: Temporal control and selective gene activation. Science 298: 1241-1245.

Huxford T, Huang DB, Malek S, Ghosh G. 1998. The crystal structure of the I $\mathrm{B} / \mathrm{NF}-\kappa \mathrm{B}$ complex reveals mechanisms of NF-кB inactivation. Cell 95: 759-770.

Inoue J, Kerr LD, Kakizuka A, Verma IM. 1992. I к B $\gamma$, a $70 \mathrm{kd}$ protein identical to the C-terminal half of p110 NF-к B: A new member of the I к B family. Cell 68: $1109-1120$.

Ishimaru N, Kishimoto H, Hayashi Y, Sprent J. 2006. Regulation of naive $\mathrm{T}$ cell function by the NF- $\mathrm{\kappa B} 2$ pathway. Nat Immunol 7: 763-772.

Jacobs MD, Harrison SC. 1998. Structure of an IкB/NF-кB complex. Cell 95: 749-758.

Kearns JD, Basak S, Werner SL, Huang CS, Hoffmann A. 2006. IкBepsilon provides negative feedback to control NF- $\kappa$ B oscillations, signaling dynamics, and inflammatory gene expression. J Cell Biol 173: 659-664.

Kiernan R, Bres V, Ng RW, Coudart MP, El Messaoudi S, Sardet C, Jin DY, Emiliani S, Benkirane M. 2003. Post-activation turn-off of NF-к B-dependent transcription is regulated by acetylation of p65. J Biol Chem 278: $2758-2766$.

Klement JF, Rice NR, Car BD, Abbondanzo SJ, Powers GD, Bhatt PH, Chen CH, Rosen CA, Stewart CL. 1996. IкB deficiency results in a sustained NF- $\kappa \mathrm{B}$ response and severe widespread dermatitis in mice. Mol Cell Biol 16: $2341-2349$. 
Kopp EB, Ghosh S. 1995. NF-к B and rel proteins in innate immunity. Adv Immunol 58: 1-27.

Krappmann D, Scheidereit C. 2005. A pervasive role of ubiquitin conjugation in activation and termination of IкB kinase pathways. EMBO Rep 6: 321-326.

Kroll M, Margottin F, Kohl A, Renard P, Durand H, Concordet JP, Bachelerie F, Arenzana-Seisdedos F, Benarous R. 1999. Inducible degradation of IкB by the proteasome requires interaction with the F-box protein h- $\beta$ TrCP. J Biol Chem 274: 7941-7945.

Lawrence T, Bebien M, Liu GY, Nizet V, Karin M. 2005. IKK limits macrophage NF- $\mathrm{kB}$ activation and contributes to the resolution of inflammation. Nature 434: 1138-1143.

Li Q, Van Antwerp D, Mercurio F, Lee KF, Verma IM. 1999a. Severe liver degeneration in mice lacking the IкB kinase 2 gene. Science 284: 321-325.

Li ZW, Chu W, Hu Y, Delhase M, Deerinck T, Ellisman M, Johnson R, Karin M. 1999b. The IKK $\beta$ subunit of ІкB kinase (IKK) is essential for nuclear factor $\kappa \mathrm{B}$ activation and prevention of apoptosis. J Exp Med 189: 1839-1845.

Lin L, Ghosh S. 1996. A glycine-rich region in NF-кB p105 functions as a processing signal for the generation of the p50 subunit. Mol Cell Biol 16: 2248-2254.

Lin L, DeMartino GN, Greene WC. 1998. Cotranslational biogenesis of NF-кB p50 by the $26 \mathrm{~S}$ proteasome. Cell 92: 819-828.

Ling L, Cao Z, Goeddel DV. 1998. NF-кB-inducing kinase activates IKK- by phosphorylation of Ser-176. Proc Natl Acad Sci 95: 3792-3797.

Malek S, Huang DB, Huxford T, Ghosh S, Ghosh G. 2003. $\mathrm{X}$-ray crystal structure of an I $\mathrm{B} \beta \times \mathrm{NF}-\kappa \mathrm{B}$ p 65 homodimer complex. J Biol Chem 278: 23094-23100.

Massoumi R, Chmielarska K, Hennecke K, Pfeifer A, Fassler R. 2006. Cyld inhibits tumor cell proliferation by blocking Bcl-3-dependent NF-кB signaling. Cell 125: 665-677.

May MJ, Marienfeld RB, Ghosh S. 2002. Characterization of the Iк B-kinase NEMO binding domain. J Biol Chem 277: 45992-46000.

May MJ, D’Acquisto F, Madge LA, Glockner J, Pober JS, Ghosh S. 2000. Selective inhibition of NF- $\mathrm{kB}$ activation by a peptide that blocks the interaction of NEMO with the IкB kinase complex. Science 289: 1550-1554.

Mercurio F, Zhu H, Murray BW, Shevchenko A, Bennett BL, Li J, Young DB, Barbosa M, Mann M, Manning A, et al. 1997. IKK-1 and IKK-2: Cytokine-activated ІкB kinases essential for NF-кB activation. Science 278: 860-866.

Miyamoto S, Schmitt MJ, Verma IM. 1994. Qualitative changes in the subunit composition of $\kappa$ B-binding complexes during murine B-cell differentiation. Proc Natl Acad Sci 91: 5056-5060.

Moorthy AK, Savinova OV, Ho JQ, Wang VY, Vu D, Ghosh G. 2006. The $20 \mathrm{~S}$ proteasome processes NF-кB1 p105 into p50 in a translation-independent manner. $E M B O J$ 25: $1945-1956$.

Motoyama M, Yamazaki S, Eto-Kimura A, Takeshige K, Muta T. 2005. Positive and negative regulation of nuclear factor-кB-mediated transcription by ІкB-zeta, an inducible nuclear protein. $J$ Biol Chem 280: 7444-7451.
Muller CW, Rey FA, Sodeoka M, Verdine GL, Harrison SC. 1995. Structure of the NF-к B p50 homodimer bound to DNA. Nature 373: 311-317.

Naumann M, Scheidereit C. 1994. Activation of NF-к B in vivo is regulated by multiple phosphorylations. Embo J 13: 4597-4607.

Naumann M, Nieters A, Hatada EN, Scheidereit C. 1993. NF- $\mathrm{B}$ precursor p100 inhibits nuclear translocation and DNA binding of NF-к B/rel-factors. Oncogene 8: 2275-2281.

Neumann M, Grieshammer T, Chuvpilo S, Kneitz B, Lohoff M, Schimpl A, Franza BR Jr, Serfling E. 1995. RelA/p65 is a molecular target for the immunosuppressive action of protein kinase A. Embo J 14: 1991-2004.

Nolan GP, Fujita T, Bhatia K, Huppi C, Liou HC, Scott ML, Baltimore D. 1993. The bcl-3 proto-oncogene encodes a nuclear I $\kappa$ B-like molecule that preferentially interacts with NF- $\mathrm{B}$ p50 and p52 in a phosphorylationdependent manner. Mol Cell Biol 13: 3557-3566.

Pahl HL. 1999. Activators and target genes of Rel/NF-кB transcription factors. Oncogene 18: 6853-6866.

Perkins ND. 2006. Post-translational modifications regulating the activity and function of the nuclear factor $\kappa \mathrm{B}$ pathway. Oncogene 25: 6717-6730.

Perkins ND. 2007. Integrating cell-signalling pathways with NF-кB and IKK function. Nat Rev Mol Cell Biol 8: 49-62.

Rice NR, MacKichan ML, Israel A. 1992. The precursor of NF-к B p50 has I к B-like functions. Cell 71: 243-253.

Ryo A, Suizu F, Yoshida Y, Perrem K, Liou YC, Wulf G, Rottapel R, Yamaoka S, Lu KP. 2003. Regulation of NF- $\mathrm{BB}$ signaling by Pin 1-dependent prolyl isomerization and ubiquitin-mediated proteolysis of p65/RelA. Mol Cell 12: 1413-1426.

Ryseck RP, Bull P, Takamiya M, Bours V, Siebenlist U, Dobrzanski P, Bravo R. 1992. RelB, a new Rel family transcription activator that can interact with p50-NF-к B. Mol Cell Biol 12: 674-684.

Saccani S, Marazzi I, Beg AA, Natoli G. 2004. Degradation of promoter-bound p65/RelA is essential for the prompt termination of the nuclear factor $\kappa \mathrm{B}$ response. $J$ Exp Med 200: 107-113.

Scheidereit C. 2006. ІкаВ kinase complexes: Gateways to NF- $\kappa \mathrm{B}$ activation and transcription. Oncogene 25: 6685-6705.

Schreiber J, Jenner RG, Murray HL, Gerber GK, Gifford DK, Young RA. 2006. Coordinated binding of NF- $\mathrm{\kappa B}$ family members in the response of human cells to lipopolysaccharide. Proc Natl Acad Sci 103: 5899-5904.

Sen R, Baltimore D. 1986a. Inducibility of $\kappa$ immunoglobulin enhancer-binding protein NF- $\mathrm{K}$ B by a posttranslational mechanism. Cell 47: 921-928.

Sen R, Baltimore D. 1986b. Multiple nuclear factors interact with the immunoglobulin enhancer sequences. Cell 46: 705-716.

Senftleben U, Cao Y, Xiao G, Greten FR, Krahn G, Bonizzi G, Chen Y, Hu Y, Fong A, Sun SC, et al. 2001. Activation by IKK of a second, evolutionary conserved, NF- $\mathrm{K}$ B signaling pathway. Science 293: 1495-1499.

Sil AK, Maeda S, Sano Y, Roop DR, Karin M. 2004. ІкB kinase- acts in the epidermis to control skeletal and craniofacial morphogenesis. Nature 428: 660-664. 
A. Oeckinghaus and S. Ghosh

Solan NJ, Miyoshi H, Carmona EM, Bren GD, Paya CV. 2002. RelB cellular regulation and transcriptional activity are regulated by p100. J Biol Chem 277: 1405-1418.

Suyang H, Phillips R, Douglas I, Ghosh S. 1996. Role of unphosphorylated, newly synthesized $\mathrm{I} \kappa \mathrm{B} \beta$ in persistent activation of NF-к B. Mol Cell Biol 16: 5444-5449.

Tam WF, Sen R. 2001. IкB family members function by different mechanisms. J Biol Chem 276: 7701-7704.

Tanaka T, Grusby MJ, Kaisho T. 2007. PDLIM2-mediated termination of transcription factor NF- $\mathrm{KB}$ activation by intranuclear sequestration and degradation of the p65 subunit. Nat Immunol 8: 584-591.

Thompson JE, Phillips RJ, Erdjument-Bromage H, Tempst $\mathrm{P}$, Ghosh S. 1995. I к B- $\beta$ regulates the persistent response in a biphasic activation of NF-к B. Cell 80: 573-582.

Udalova IA, Mott R, Field D, Kwiatkowski D. 2002. Quantitative prediction of NF-к B DNA-protein interactions. Proc Natl Acad Sci 99: 8167-8172.

Vermeulen L, De Wilde G, Van Damme P, Vanden Berghe W, Haegeman G. 2003. Transcriptional activation of the NF-кB p65 subunit by mitogen- and stress-activated protein kinase-1 (MSK1). EMBO J 22: 1313-1324.

Wang D, Westerheide SD, Hanson JL, Baldwin AS Jr. 2000. Tumor necrosis factor-induced phosphorylation of RelA/p65 on Ser529 is controlled by casein kinase II. J Biol Chem 275: 32592-32597.

Wessells J, Baer M, Young HA, Claudio E, Brown K, Siebenlist U, Johnson PF. 2004. BCL-3 and NF-кB p50 attenuate lipopolysaccharide-induced inflammatory responses in macrophages. $J$ Biol Chem 279: 49995-50003.

Wissink S, van de Stolpe A, Caldenhoven E, Koenderman L, van der Saag PT. 1997. NF-к B/Rel family members regulating the ICAM-1 promoter in monocytic THP-1 cells. Immunobiology 198: 50-64.

Woronicz JD, Gao X, Cao Z, Rothe M, Goeddel DV. 1997. I $\mathrm{B}$ kinase- $\beta$ : NF- $\kappa \mathrm{B}$ activation and complex formation with ІкB kinase- and NIK. Science 278: 866-869.

Wu C, Ghosh S. 1999. $\beta$-TrCP mediates the signal-induced ubiquitination of ІкBß. J Biol Chem 274: 29591-29594.
Wulczyn FG, Naumann M, Scheidereit C. 1992. Candidate proto-oncogene bcl-3 encodes a subunit-specific inhibitor of transcription factor NF-к B. Nature 358: 597-599.

Xiao G, Fong A, Sun SC. 2004. Induction of p100 processing by NF-кB-inducing kinase involves docking IкB kinase (IKK) to p100 and IKK-mediated phosphorylation. J Biol Chem 279: 30099-30105.

Yamamoto M, Yamazaki S, Uematsu S, Sato S, Hemmi H, Hoshino K, Kaisho T, Kuwata H, Takeuchi O, Takeshige K, et al. 2004. Regulation of Toll/IL-1-receptor-mediated gene expression by the inducible nuclear protein ІкBzeta. Nature 430: 218-222.

Yamamoto Y, Verma UN, Prajapati S, Kwak YT, Gaynor RB. 2003. Histone H3 phosphorylation by IKK- is critical for cytokine-induced gene expression. Nature 423: 655-659.

Yamazaki S, Muta T, Matsuo S, Takeshige K. 2005. Stimulus-specific induction of a novel nuclear factor- $\mathrm{B}$ regulator, IкB-zeta, via Toll/Interleukin-1 receptor is mediated by mRNA stabilization. J Biol Chem 280: 1678-1687.

Yaron A, Hatzubai A, Davis M, Lavon I, Amit S, Manning AM, Andersen JS, Mann M, Mercurio F, Ben-Neriah Y. 1998. Identification of the receptor component of the IкB $\alpha$-ubiquitin ligase. Nature 396: 590-594.

Yeung F, Hoberg JE, Ramsey CS, Keller MD, Jones DR, Frye RA, Mayo MW. 2004. Modulation of NF-кB-dependent transcription and cell survival by the SIRT1 deacetylase. EMBO J 23: 2369-2380.

Zandi E, Chen Y, Karin M. 1998. Direct phosphorylation of IкB by IKK and IKK $\beta$ : Discrimination between free and NF-кB-bound substrate. Science 281: 1360-1363.

Zandi E, Rothwarf DM, Delhase M, Hayakawa M, Karin M. 1997. The IкB kinase complex (IKK) contains two kinase subunits, IKK and IKK $\beta$, necessary for IкB phosphorylation and NF-кB activation. Cell 91: 243-252.

Zhong H, Voll RE, Ghosh S. 1998. Phosphorylation of NF-к B p65 by PKA stimulates transcriptional activity by promoting a novel bivalent interaction with the coactivator CBP/p300. Mol Cell 1: 661-671.

Zhong H, May MJ, Jimi E, Ghosh S. 2002. The phosphorylation status of nuclear NF- $\kappa$ B determines its association with CBP/p300 or HDAC-1. Mol Cell 9: 625-636. 


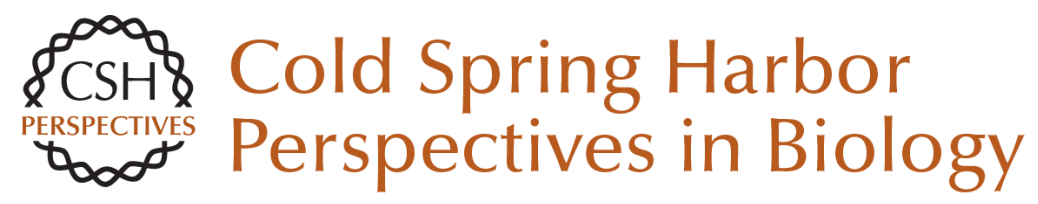

\section{The NF- $\kappa B$ Family of Transcription Factors and Its Regulation}

Andrea Oeckinghaus and Sankar Ghosh

Cold Spring Harb Perspect Biol 2009; doi: 10.1101/cshperspect.a000034 originally published online September 2, 2009

\section{Subject Collection NF-kB}

Use of Forward Genetics to Discover Novel

Regulators of NF- $\mathrm{KB}$ Tao Lu and George R. Stark

Selectivity of the NF-kB Response Ranjan Sen and Stephen T. Smale

NF- $\kappa B$ in the Nervous System Barbara Kaltschmidt and Christian Kaltschmidt

Signaling to NF- $\kappa B$ : Regulation by Ubiquitination Ingrid E. Wertz and Vishva M. Dixit

Ubiquitination and Degradation of the Inhibitors of NF- $\kappa B$

Naama Kanarek, Nir London, Ora Schueler-Furman, et al.

A Structural Guide to Proteins of the NF- $\mathrm{KB}$ Signaling Module

Tom Huxford and Gourisankar Ghosh

NF-kB in the Immune Response of Drosophila Charles Hetru and Jules A. Hoffmann

\section{Control of NF-kB-dependent Transcriptional}

Responses by Chromatin Organization Gioacchino Natoli
Oncogenic Activation of NF- $\mathrm{kB}$

Louis M. Staudt

The Regulatory Logic of the NF- $\mathrm{kB}$ Signaling

System Ellen O'Dea and Alexander Hoffmann

Roles of the NF- $k B$ Pathway in Lymphocyte

Development and Function

Steve Gerondakis and Ulrich Siebenlist

The IKK Complex, a Central Regulator of NF- $\mathrm{KB}$

Activation Alain Israël

NF- $\kappa B$ in the Nervous System

Barbara Kaltschmidt and Christian Kaltschmidt

The Nuclear Factor NF- $\kappa B$ Pathway in Inflammation

Toby Lawrence

NF- $\kappa$ B as a Critical Link Between Inflammation and Cancer Michael Karin

Specification of DNA Binding Activity of NF-KB Proteins

Fengyi Wan and Michael J. Lenardo

For additional articles in this collection, see http://cshperspectives.cshlp.org/cgi/collection/

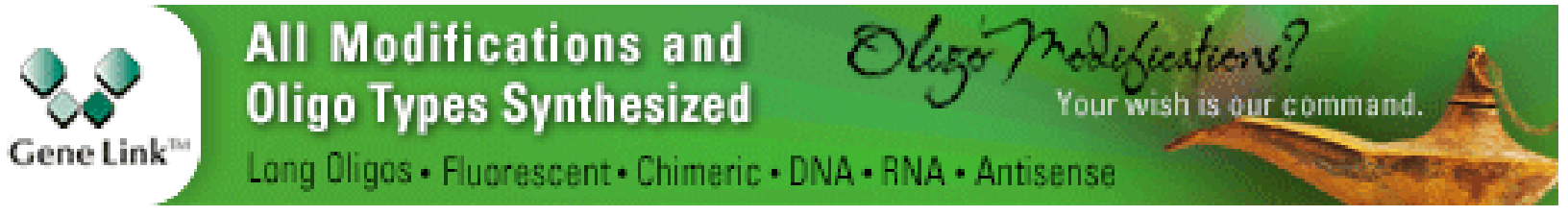

Copyright @ 2009 Cold Spring Harbor Laboratory Press; all rights reserved 